ZOOLOGIA 32(5): 403-408, October 2015

http://dx.doi.org/10.1590/S1984-46702015000500009

\title{
Notes on Neotropical Proconiini (Insecta: Hemiptera: Cicadellidae). VIII: morphology of the male and female genitalia of Paraulacizes munda, revalidated from synonymy of $P$. confusa
}

\author{
Gabriel Mejdalani1,* \& Rodney Ramiro Cavichioli ${ }^{2}$
}

\begin{abstract}
'Departamento de Entomologia, Museu Nacional, Universidade Federal do Rio de Janeiro. Quinta da Boa Vista, São Cristóvão, 20940-040 Rio de Janeiro, RJ, Brazil.

2Departamento de Zoologia, Setor de Ciências Biológicas, Universidade Federal do Paraná. Caixa Postal 19020, 81531-980 Curitiba, PR, Brazil. E-mail: cavich@ufpr.br

*Corresponding author. E-mail: mejdalan@acd.ufrj.br
\end{abstract}

\begin{abstract}
Paraulacizes munda (Fowler, 1899) has been considered a junior synonym of $P$. confusa (Signoret, 1855). These two species were described from Mexico. Here it is shown that $P$. munda can be distinguished from $P$. confusa by the color and size of the body. Hence, the former is revalidated from synonymy of the latter. Descriptions and illustrations of the male and female genitalia of $P$. munda, which are necessary for an accurate identification of leafhopper species in general, are provided for the first time. Paraulacizes munda can be distinguished from the other 11 species currently included in Paraulacizes by the following combination of features: ground color of anterior dorsum yellow or pale yellow; dorsal processes of male pygofer strongly inflated apically; style with apex transversely truncate, not projected inward; atrial processes of aedeagus, in lateral view, not distinctly curved apically; female sternite VII with small median lobe on posterior margin and pair of dark brown marks posteromedially. This is the first detailed description of the first and second ovipositor valvulae of a Paraulacizes species. The female genitalia of Paraulacizes are compared with those of the related genera Aulacizes Amyot \& Serville, 1843 and Proconosama Young, 1968.
\end{abstract}

KEY WORDS. Auchenorrhyncha; Cicadellinae; leafhopper; sharpshooter; taxonomy.

The proconiine Paraulacizes Young, 1968 (type species: Cicada irrorata Fabricius, 1794) is recorded from the Nearctic and Neotropical regions (from southeastern and central United States to Panama) and is considered closely related to Aulacizes Amyot \& Serville, 1843 (Young 1968). It can be distinguished from the latter, and from other genera of Proconiini, by the usually inflated shape of the male dorsal pygofer processes and by the elongate basiventral aedeagal processes (Young 1968: 94, fig. 82). Eleven species are currently recognized in Paraulacizes (TakiYa 2007, McKamey 2007, Wilson et al. 2009).

The sharpshooter Tettigonia confusa was described by SignORET (1855) based on material from Mexico. WALKER (1858) transferred T. confusa to Aulacizes. Melichar (1926) redescribed the species (also in Aulacizes) and considered Oncometopia munda Fowler, 1899 (from Guerrero, Mexico) as its junior subjective synonym. Young (1968) transferred T. confusa to Paraulacizes and included it in his key to 10 of the 11 currently known species of the genus; he accepted the synonymy proposed by Melichar (1926) and provided illustrations of the anterior dorsum (crown, pronotum, and mesonotum) and sternite VII of the female lectotype of $O$. munda.

Here it is shown that $P$. munda can be distinguished from $P$. confusa by the color and size of the body. Hence, the former is revalidated from its synonymy with the latter. Descriptions and illustrations of the male and female genitalia of $P$. munda, which are necessary for an accurate identification of leafhopper species in general, are herein provided for the first time. Although Kramer (1950) gave a general description of the female genitalia of the type species, P. irrorata (treated as Aulacizes irrorata), as part of his study on the morphology and phylogeny of the Auchenorrhyncha, the present paper includes the first detailed description of the first and second ovipositor valvulae of a Paraulacizes species. The female genitalia of Paraulacizes are compared with those of the related genera Aulacizes and Proconosama Young, 1968. This is the eighth contribution of a series on the taxonomy of the Proconiini from the Neotropical region. Previous papers of the series (listed by Mejdalani \& Silva 2010) included descriptions of four new species and notes on other species in the tribe.

\section{MATERIAL AND METHODS}

Techniques for preparation of the male and female genitalia follow OMAN (1949) and MejDALANi (1998), respectively. Dissected parts are stored in small vials with glycerin and attached below the specimens, as suggested by Young \& BeIRne (1958).

2015 | Sociedade Brasileira de Zoologia | www.sbzoologia.org.br | www.scielo.br/zool All content of the journal, except where identified, is licensed under a Creative Commons attribution-type BY. 
Temporary slides of the ovipositor valvulae, with glycerin, were mounted. Photographs were taken with digital cameras attached to a stereomicroscope or to a light microscope. In most cases, CombineZP, free software developed by Alan Hadley, was employed to produce a single photograph from a stack of images. The descriptive terminology adopted herein follows mainly Young (1968), except for the facial areas of the head (Hamilton 1981, Mejdalani 1993, 1998) and the female genitalia (SNodgrass 1933, Nielson 1965, Hill 1970). Use of the term gonoplac (= third ovipositor valvula) and the names of the sculptured areas of the first ovipositor valvulae follow MejDaLANI (1998). The specimens studied (one male and one female) belong to the Museum für Tierkunde (MTD, Dresden). Other institutions cited in this paper are the Naturhistorisches Museum (NHMW, Vienna) and The Natural History Museum (BMNH, London). Label data are quoted exactly with a reversed virgule $(\backslash)$ separating lines on a label and a semicolon separating labels.

\section{TAXONOMY}

\section{Paraulacizes munda (Fowler, 1899), revalidated}

Figs. 1-17

Oncometopia munda Fowler, 1899: 232, tab. 14, fig. 21 [new species, illustrated, comparative note], Young, 1965 [lectotype designated].

Aulacizes confusa (Signoret, 1855): Melichar, 1926 [senior synonym of $O$. munda], Metcalf, 1965 [catalogue].

Paraulacizes confusa: Young, 1968 [new combination, synonym of O. munda confirmed], McKamey, 2007 [catalogue].

Material examined. One male, one female: "Jalapa \Mexico"; "1918"; "coll. A. JACOBI" (MTD).

Length of male $10.6 \mathrm{~mm}$, female $11.5 \mathrm{~mm}$.

Head (Fig. 1). Median length of crown approximately 1/ 3 of interocular width and $1 / 5$ of transocular width. Crown with anterior margin broadly rounded and slightly carinate medially, with slight median longitudinal fovea, without Mshaped elevation bordering posterior margin, disc pubescent; ocelli located slightly before imaginary line between anterior angles of eyes, each approximately equidistant between adjacent anterior eye angle and median line of crown; antennal ledges, in dorsal view, with longitudinal fovea and, in lateral view, slightly carinate dorsally. Face pubescent; frons swollen, with distinct muscle impressions, median portion slightly depressed; epistomal suture incomplete medially; clypeus not produced, its contour continuing profile of frons.

Thorax (Fig. 1). Pronotal width approximately equal to transocular width; lateral margins of pronotum slightly convergent anteriorly, posterior margin distinctly emarginate medially; pronotal disc coarsely punctate and pubescent; dorsopleural carinae complete, approximately rectilinear, declivous anteriorly. Mesonotum with scutellum transversely striated. Forewings coriaceous, not densely punctate; membrane well delimited, including apical cells and distal portion of anteapical cells; veins elevated and distinct; with three closed anteapical cells and four apical cells, base of fourth slightly more proximal than base of third; with few (about two or three) additional anteapical crossveins to costal margin. Hind wings with vein $\mathrm{R}_{2+3}$ complete. Hind legs with femoral setal formula 2:0:0; length of first tarsomere smaller than combined length of second and third.

Color (Figs. 1, 17). Anterior dorsum yellow or pale yellow, except for yellowish-orange scutellum, with dark brown marks as follows: crown with basal small triangle, median longitudinal complete line, and pair of curved lines extending from near ocelli to apical portion, bordering upper limit of muscle impressions of frons and connected posteriorly to longitudinal line over each temporal suture; pronotum with pair of curved lines on anterior third behind eyes and pair of longer curved lines on posterior half, almost touching each other medially, smaller marks also present on pronotal disc; mesonotum with irregular maculae basally and pair of lines over transverse sulcus. These dark brown marks of anterior dorsum are variable and may not be present. Forewings yellowish-green or violaceous with numerous irregular dark brown vermiculations and small marks, with more conspicuous dark brown line at border between corium and membrane. Face yellow or pale yellow with dark brown marks as follows: median portion of frons with or without pair of lines converging toward median coronal line, lateral portions of frons with oblique row of spots below antenna; genae with vertical mark below compound eye. Lateral and ventral portions of thorax and legs pale yellow or yellow tinged with orange at various parts. Abdominal sternites and laterotergites pale yellow or yellow; sternites with dark brown marks basally and medially; tergites mostly dark brown; female sternite VII (Fig. 9) with pair of dark brown marks posteromedially.

Male genitalia. Pygofer (Figs. 2-3; PYL), in lateral view, small, not strongly produced posteriorly; posterior margin broadly rounded; dorsal margin with conspicuous process extending beyond ventral margin and strongly inflated apically (Figs. 2-3; PYP); pygofer surface with elongate microsetae distributed mostly on posterior and ventral portions. Valve (Fig. 4; VAL), in ventral view, short, subrectangular. Subgenital plates (Figs. 4-5; SGP), in ventral view, triangular, separated throughout their length, surface with numerous scattered microsetae; in lateral view, extending posteriorly slightly beyond pygofer apex, distal half strongly curved dorsally, basal half with sclerotized dentiform projection associated with style apex (Fig. 5; DPP). Style (Fig. 5), in dorsal view, with distinct preapical lobe, with few serially arranged microsetae located beyond preapical lobe; apex transversely truncate, not projected inward. Connective (Fig. 5), in dorsal view, elongate, narrowly Y-shaped, stem much longer than slightly divergent arms. Aedeagus (Figs. 6-7) symmetrical; preatrium distinct (Fig. 6, PAT); shaft, in lateral view, short, directed dorsally; atrium with pair of dorsally-directed processes which exceed shaft apex (Figs. 6-7, APR); in caudal 

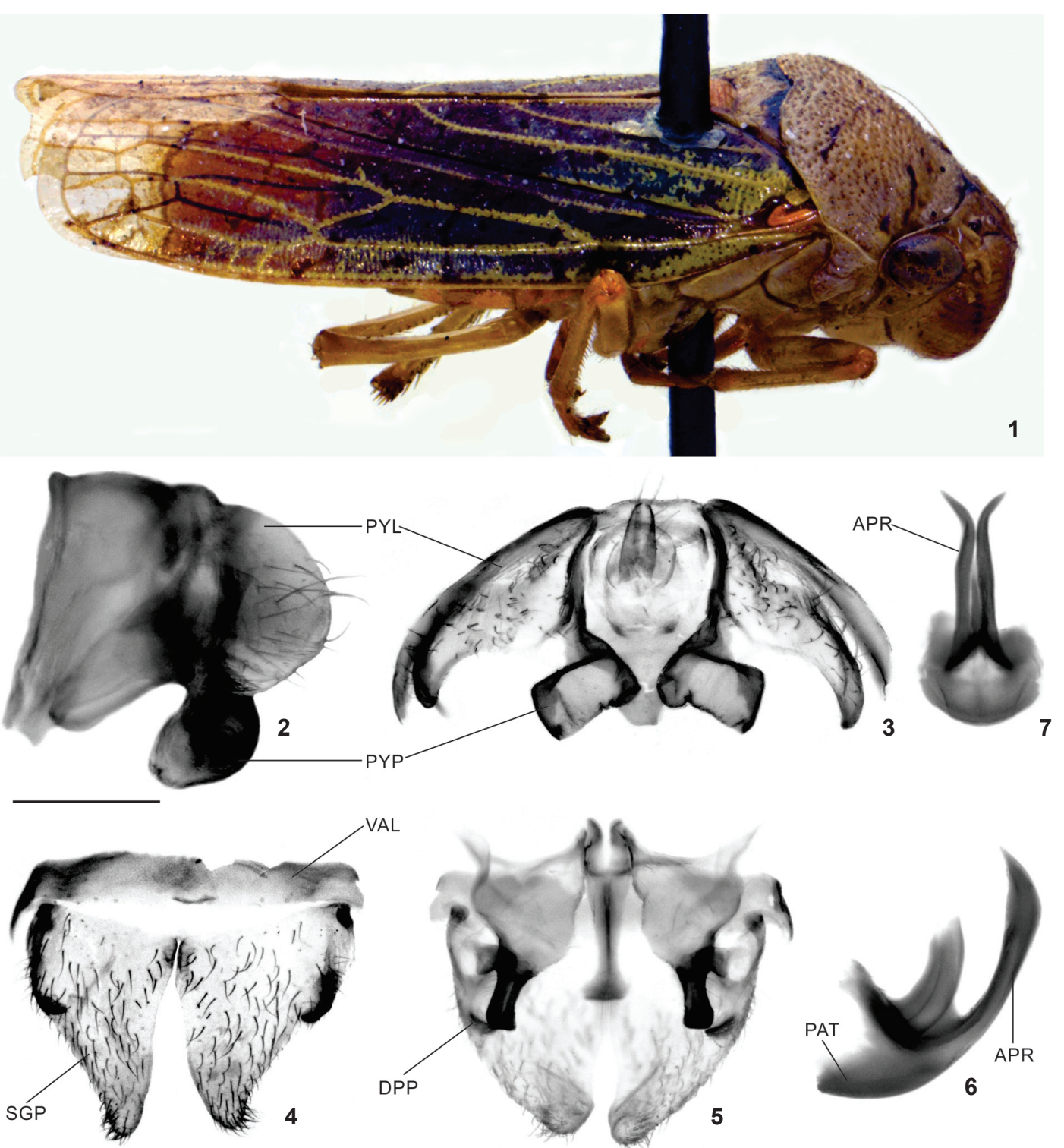

Figures 1-7. Paraulacizes munda, male: (1) body (length $10.6 \mathrm{~mm}$ ), laterodorsal view. (2-7) genitalia: (2) pygofer, lateral view; (3) pygofer, caudal view; (4) valve and subgenital plates, ventral view; (5) valve, subgenital plates, styles, and connective, dorsal view; (6) aedeagus, lateral view; (7) aedeagus, caudal view. (APR) aedeagal process; (DPP) dentiform projection of subgenital plate; (PAT) preatrium; (PYL) pygofer lobe; (PYP) pygofer process; (SGP) subgenital plate; (VAL) valve. Scale bar for Fig. $2=0.5 \mathrm{~mm}$.

view, processes adjacent to each other except for divergent apical portion; in lateral view, apex of processes not distinctly curved.

Female genitalia. Sternite VII (Figs. 8-9) not strongly produced posteriorly; posterior margin transverse with slight median lobe; lateroposterior portions rounded. "Internal" sternite VIII without distinct sclerites. Pygofer (Figs. 8-9, PYL), in lateral view, moderately produced posteriorly; posterior margin broadly rounded; setae distributed on most of surface, absent basidorsally. Gonoplacs (Figs. 8-9, GON) extending slightly beyond pygofer apex, also bearing setae. Valvifers I (Fig. 10, VLI), in lateral view, ellipsoid. Valvulae I (Fig. 10), in lateral view, with blade expanded, apex acute; dorsal sculptured area extending from basal portion to apex of blade, formed by horizontal lines basally (Fig. 11, DSA) and scale-like processes arranged in oblique lines apically (Fig. 12, DSA); ventral sculptured area restricted to apical portion of blade, formed by scale-like processes; ventral interlocking device elongate, located on basiventral half of blade; in ventral view, valvulae I without basal modifications. Valvulae II 


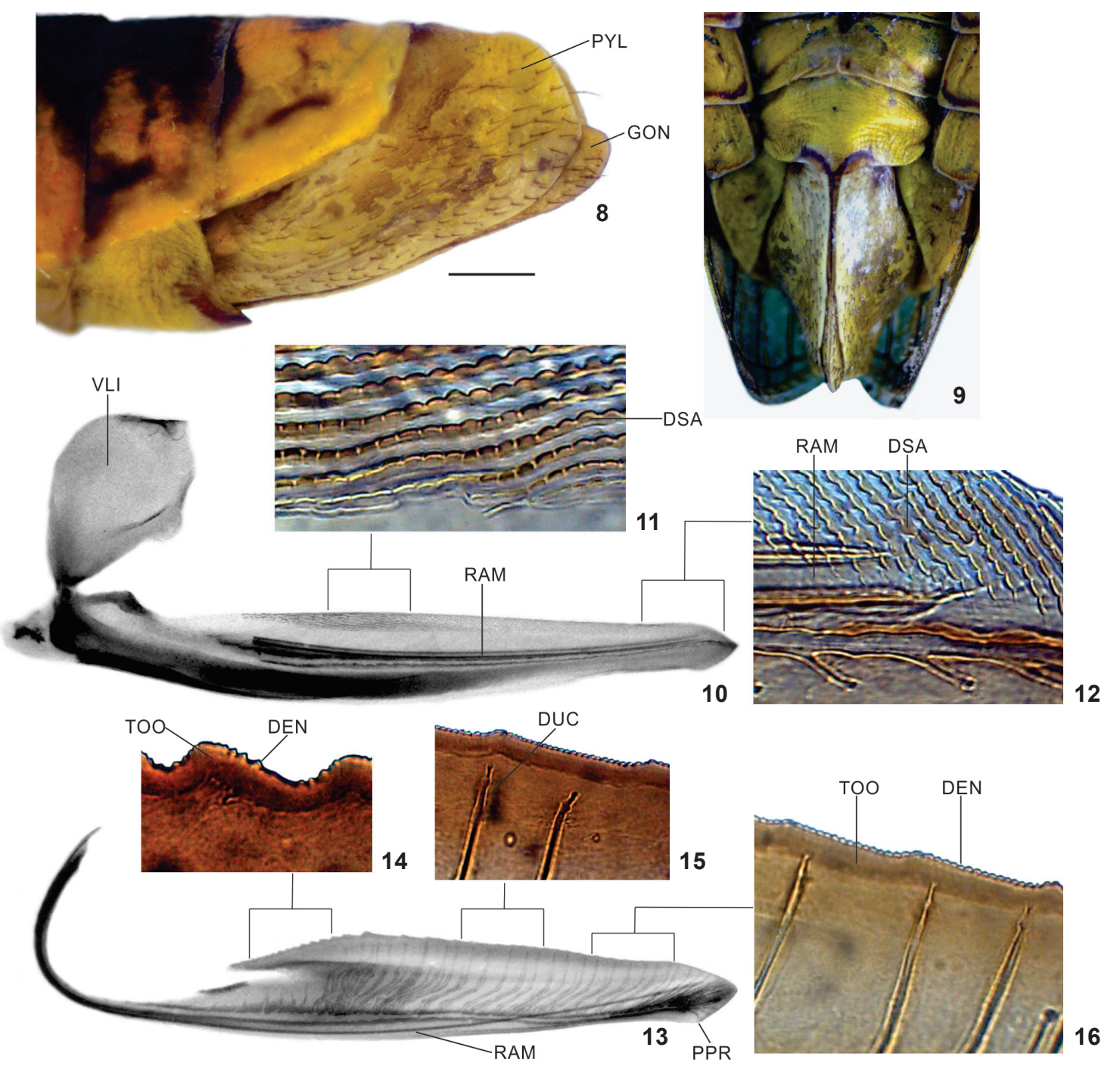

Figures 8-16. Paraulacizes munda, female: (8-9) apical portion of abdomen in lateral and ventral views, respectively; (10) valvifer I and valvula I, lateral view (the ramus of valvula I is broken basally); (11-12) dorsal sculptured area at basal and apical portions, respectively; (13) valvula II, lateral view; (14-16) teeth at basal (ascending), median and apical (both descending) portions, respectively. (DEN) denticle; (DSA) dorsal sculptured area; (DUC) duct; (GON) gonoplac; (PPR) preapical prominence; (PYL) pygofer lobe; (RAM) ramus; (TOO) tooth; (VLI) valvifer I. Scale bar for Fig. $8=0.5 \mathrm{~mm}$.

(Fig. 13), in lateral view, distinctly expanded beyond basal curvature and then gradually narrowed toward apex, the latter obtuse; preapical prominence distinct (Fig. 13, PPR); dorsal margin with about 35 continuous teeth, teeth on ascending portion (Fig. 14, TOO) taller and shorter than those on descending portion (Figs. 15-16, TOO), the latter very elongate, low and flat; denticles (Figs. 14-16, DEN) distributed on teeth and on dorsal and ventral apical portions of blade, dorsal dentate apical portion much longer than ventral one; blade with ducts (Figs. 1516, DUC) extending toward apex and toward teeth or terminating well below the latter.
Remarks. The lectotype of Oncometopia munda is a female (BMNH; Fig. 17 - body in dorsal view). The lectotype of Tettigonia confusa, a male (NHMW; Fig. 18 - body in dorsal view), was designated by Young \& BeIER (1963).

\section{DISCUSSION}

Our interpretation of $P$. munda is in accordance with the original description and illustration of FowLER (1899), as well as with the illustrations provided by Young (1968) of the anterior dorsum and sternite VII of the female lectotype of this species. 


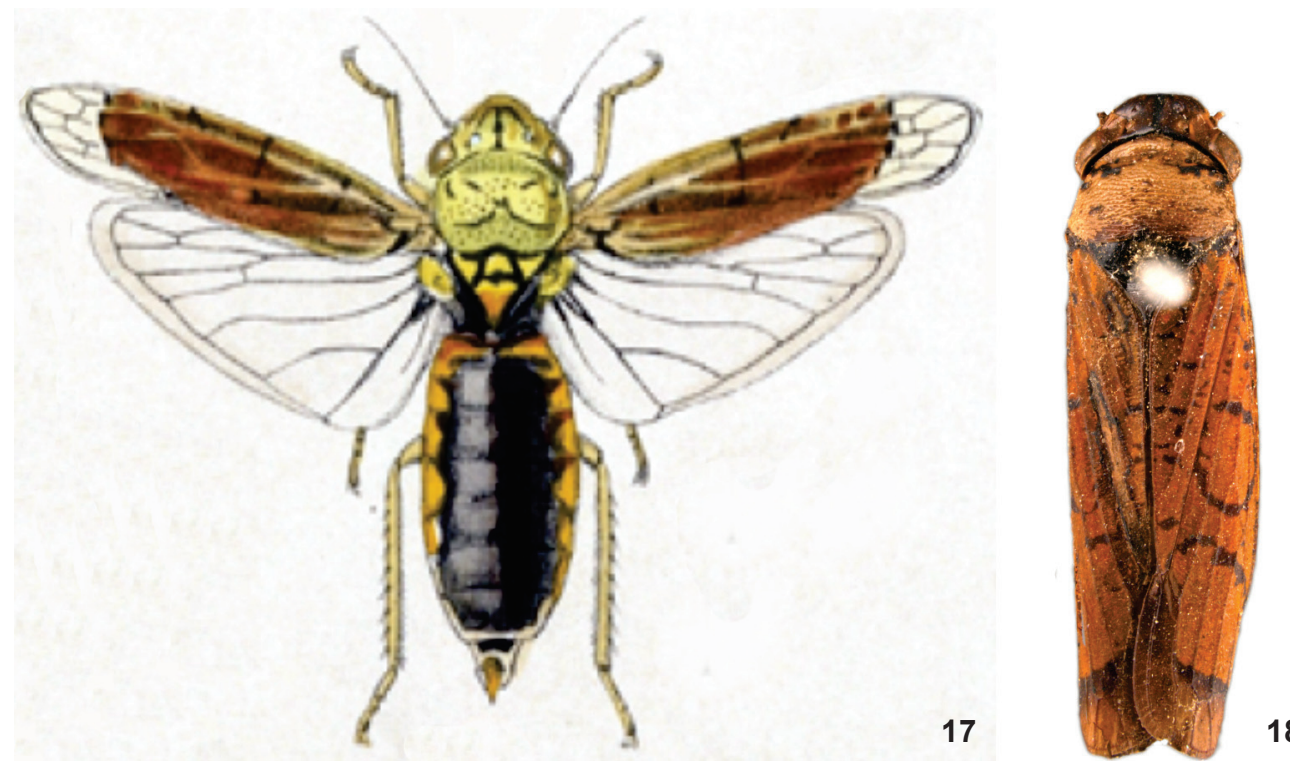

Figures 17-18. Habitus of lectotypes of Paraulacizes species, dorsal view. (17) female lectotype (length 11 mm) of Oncometopia munda (reproduced from Fowler 1899: tab. 14, fig. 21); (18) male lectotype (length 14 mm) of Tettigonia confusa ( ${ }^{\circ}$ Natural History Museum Vienna, Hemiptera Image Collection; published with permission).

In P. munda, the ground color of the anterior dorsum is yellow or pale yellow (Figs. 1, 17, the latter reproduced from FowLer 1899: tab. 14, fig. 21), whereas the ground color of the whole dorsum is brown in P. confusa (Fig. 18). Paraulacizes munda has at most narrow dark brown lines on crown (Fig. 17), whereas most of the coronal disc of $P$. confusa is covered by a large dark brown area (Fig. 18). In addition, the male of $P$. munda is 10.6 $\mathrm{mm}$ long, whereas that of $P$. confusa is $14.0 \mathrm{~mm}$ long (SIGNORET $1855)$. Based on the color pattern, we conclude that the specimen portrayed by WiLson et al. (2009) as $P$. confusa is actually $P$. munda. The latter species can be distinguished from the other ones of the genus by the following combination of features: dorsal processes of male pygofer strongly inflated apically (Figs. 2-3); style with apex transversely truncate (Fig. 5), not projected inward (Young 1968: 96 described this kind of apex as "not toed in"); atrial processes of aedeagus, in lateral view, not distinctly curved apically (Fig. 6); female sternite VII with small median lobe on posterior margin and pair of dark brown marks posteromedially (Fig. 9). The presence of the inflated apical portion of the pygofer process supports the assignment of $P$. munda to Paraulacizes, as this feature is observed in the type species, $P$. irrorata (Young 1968). The presence of the dorsal pygofer process is probably a homologous feature shared by members of the closely related genera (Young 1968) Aulacizes, Paraulacizes, Pseudometopia Schmidt, 1928, Proconosama, Amblydisca Stål, 1869, and Proconopera Young, 1968.

Among the genera considered related to Paraulacizes, detailed descriptions of the female genitalia are available for Aulacizes (Mejdalani et al. 2006) based on A. erythrocephala
(Germar, 1821) and Proconosama (Mejdalani et al. 2012) based on P. alalia (Distant, 1908). Sclerites were not observed in the "internal" sternite VIII of Paraulacizes munda, whereas a pair of lobed sclerotized areas were found medially in Aulacizes and a pair of elongate sclerotized areas were found laterally in Proconosama. The valvulae II of Paraulacizes (Fig. 13) and Aulacizes are expanded at the basal portion, whereas those of Proconosama are expanded at the median portion. Denticles are present on the teeth located at the ascending and descending portions of the valvula II of Paraulacizes (Figs. 14-16) and Aulacizes, whereas those on the elongate ascending portion of Proconosama do not bear denticles. The teeth located at the descending portion of the blade of Paraulacizes are considered peculiar because they are elongate, low, and flat (Figs. 15-16). These teeth differ greatly from those of Aulacizes and Proconosama species, which are distinctly produced dorsally. In Proconosama, about 12 of the proximal ducts of valvula II are located very close to each other, forming a distinct group, a condition that has not been observed in Paraulacizes (Fig. 13) and Aulacizes. This preliminary comparison of the female genitalia suggests that features of potential taxonomic interest are present in the "internal" sternite VIII and valvula II of these three related genera.

\section{ACKNOWLEDGMENTS}

The manuscript benefited from the very useful comments of Zoologia associated editor Ângelo Pinto and two anonymous reviewers. Rainer Emmrich (MTD; retired) kindly sent us on 
loan many years ago a small collection of proconiines for study, including the $P$. munda specimens herein described. Herbert Zettel (NHMW) kindly sent us the photograph and information on the lectotype of $P$. confusa. Research productivity fellowships from Conselho Nacional de Desenvolvimento Científico e Tecnológico (CNPq) are acknowledged (process $303627 / 2014-0$ to GM and 305484/2014-1 to RRC).

\section{LITERATURE CITED}

Fowler FF (1899) Order Rhynchota. Suborder HemipteraHomoptera (continued). Biologia Centrali-Americana; contributions to the knowledge of the fauna and flora of Mexico and Central America 2: 225-232.

Hamilton KGA (1981) Morphology and evolution of the rhynchotan head (Insecta: Hemiptera, Homoptera). Canadian Entomologist 113: 953-974. doi: 10.4039/Ent113953-11

HILL BG (1970) Comparative morphological study of selected higher categories of leafhoppers (Homoptera: Cicadellidae). Ann Arbor, University Microfilms, xi+187p.

KRAMER S (1950) The morphology and phylogeny of auchenorhynchous Homoptera (Insecta). Illinois Biological Monographs 20: $1-111$

McKamey SH (2007) Taxonomic catalogue of the leafhoppers (Membracoidea). Part 1. Cicadellinae. Memoirs of the American Entomological Institute 78: 1-394.

Mejdalani G (1993) Morfologia da cabeça de Versigonalia ruficauda (Walker, 1851), com notas sobre a terminologia (Homoptera, Cicadellidae, Cicadellinae). Revista Brasileira de Entomologia 37: 279-288.

Mejdalani G (1998) Morfologia externa dos Cicadellinae (Homoptera, Cicadellidae): comparação entre Versigonalia ruficauda (Walker) (Cicadellini) e Tretogonia cribrata Melichar (Proconiini), com notas sobre outras espécies e análise da terminologia. Revista Brasileira de Zoologia 15: 451-544. doi: 10.1590/S0101-81751998000200015

Mejdalani G, Takiya DM, Carvalho RA (2006) Notes on Neotropical Proconiini (Hemiptera: Cicadellidae: Cicadellinae), IV: lectotype designations of Aulacizes Amyot \& Audinet-Serville species described by Germar and revalidation of A. erythrocephala (Germar, 1821). Arthropod Systematics and Phylogeny 64: 105-111.

Mejdalani G, Silva RS (2010) Notes on Neotropical Proconiini (Hemiptera: Cicadellidae: Cicadellinae). VII: First detailed description of the female genitalia of a Diestostemma species. Zoologia 27: 813-819. doi: 10.1590/S1984-46702010000500018
Mejdalani G, Cavichioli RR, Carvalho RA (2012) Proconosama takiyae, a new sharpshooter from Ecuador, the female of $P$. alalia (Distant), and a key to the species of the genus (Hemiptera: Cicadellidae: Cicadellinae: Proconiini). Zootaxa 3525: 75-82.

Melichar L (1926) Monographie der Cicadellinen. III. Annales Historico-Naturales Musei Nationalis Hungarici 23: 273-394.

Metcalf ZP (1965) General catalogue of the Homoptera. Fascicle VI, Cicadelloidea. Part 1, Tettigellidae. Washington, D.C., Agricultural Research Service, United States Department of Agriculture, 730p.

Nielson MW (1965) A revision of the genus Cuerna (Homoptera, Cicadellidae). Technical Bulletin of the United States Department of Agriculture 1318: 1-48.

Oman PW (1949) The Nearctic leafhoppers (Homoptera: Cicadellidae). A generic classification and check list. Memoirs of the Entomological Society of Washington 3: 1-253.

Signoret V (1855) Revue iconographique des Tettigonides. Annales de la Société Entomologique de France 3: 49-60.

SNodgrass RE (1933) Morphology of the insect abdomen. Part II. The genital ducts and the ovipositor. Smithsonian Miscellaneous Collections 89: 1-148.

TAKIYA DM (2007) Genus Paraulacizes Young, 1968. Available online at: http://takiya.speciesfile.org/taxahelp.asp?key= Proconia\&keyN=1\&lng=En\&hc=1581 [Accessed: 03/05/2015]

WALKER F (1858) List of the specimens of Homopterous insects in the collection of the British Museum. Supplement. Printed by order of the trustees, 307p.

Wilson MR, Turner J, McKamey SH (2009) Sharpshooter leafhoppers of the world (Hemiptera: Cicadellidae subfamily Cicadellinae). Available online at: http://naturalhistory. museumwales.ac.uk/sharpshooters/home.php [Accessed: 20/ 04/2015]

Young DA (1965) Cicadelline types in the British Museum (Natural History) (Homoptera: Cicadellidae). Bulletin of the British Museum (Natural History) Entomology 17: 163-169.

Young DA (1968) Taxonomic study of the Cicadellinae (Homoptera: Cicadellidae). Part 1, Proconiini. Bulletin of the United States National Museum 261: 1-287.

Young DA, BeIRne BP (1958) A taxonomic revision of the leafhopper genus Flexamia and a new related genus (Homoptera: Cicadellidae). Technical Bulletin of the United States Department of Agriculture 1173: 1-53.

Young DA, Beier M (1963) Types of Cicadellinae (Homoptera: Cicadellidae) in the Natural History Museum in Vienna. Annalen des Naturhistorischen Museums in Wien 67: 565-575.

Submitted: 15 June 2015

Received in revised form: 6 August 2015

Accepted: 29 August 2015

Editorial responsibility: Ângelo Parise Pinto 